\title{
The U.S. Withdrawal From the Paris Agreement
}

\author{
Challenges and \\ Opportunities for China
}

Yu Hongyuan

\begin{abstract}
President Trump's decision to withdraw the United States from the Paris Agreement on Climate Change is both a major reversal of the Obama administration's climate policy and a huge blow to global climate governance. The comprehensive regression of President Trump's climate policy manifests mainly in three aspects: abolition of the clean energy plan, exit from the Paris Agreement, and a return to traditional energy policies, which reflect the cyclical and volatile nature of the U.S. climate policy. With its lasting negative impact, the China-U.S. cooperative leadership in global climate governance is stranded. In this light, China should strive for a bigger role in leading global efforts to address climate change and enhance cooperation through various mechanisms. Under the current U.S. policy environment, China can still strengthen cooperation with the
\end{abstract}

Yu Hongyuan is Professor and Director of the Institute for Comparative Politics and Public Policy Studies, Shanghai Institutes for International Studies (SIIS), and Commissioner of CNC-FE. His mailing address is: 195-15 Tianlin Road, Shanghai 200233, China. He can also be reached at yuhongyuan@siis.org.cn.

(c) 2018 World Century Publishing Corporation and Shanghai Institutes for International Studies China Quarterly of International Strategic Studies, Vol. 4, No. 2, 281-300

DOI: $10.1142 / S 2377740018500100$

This is an Open Access article, copyright owned by the SIIS and WCPC. The article is distributed under the Creative Commons Attribution 4.0 (CC BY-NC) Licence. Further distribution of this work is permitted, provided the original work is properly cited and for non-commercial purposes. 
United States in such fields as traditional energy, infrastructure investment, global energy market, and green finance.

Keywords: Climate policy; Donald Trump; Paris Agreement; China; cooperative leadership; global governance.

Since taking office in early 2017, U.S. President Donald Trump has launched a series of policy initiatives aimed at reversing Obama-era policy directions and fulfilling his campaign promises. In terms of climate policy, President Trump announced on June 1, 2017 that the United States would withdraw from the Paris Agreement, saying that the agreement is unfair to the United States because it would negatively impact the U.S. economy and employment. Since then, the Trump administration has woven a policy network that is centered on the "America First" energy plan. The president has issued executive orders and memoranda in support of this agenda including laws, policies, regulations and guidance from the Department of Energy (DoE), the Department of the Interior (DoI), and the Environmental Protection Agency (EPA). In particular, he has adopted a domestic energy policy on revitalizing fossil fuels and the nuclear energy industry, an international energy policy aiming to strengthen energy independence and encourage energy exports, a new energy development policy centered on reduction of support for renewable energy, and a climate policy on eliminating emission constraints.

As the United States is the world's largest economy and the secondlargest greenhouse gas emitter, President Trump's adjustments to the U.S. climate and energy policies have generated profound impact on global climate governance. On the one hand, a successful U.S. low-carbon transition is important for any international climate agreement and has real effect on global low-carbon development. On the other hand, the negative attitude of the United States can also cause other countries to waver, resulting in greater destructive impact.

Although President Trump's unique personality may make the U.S. domestic and international policies appear somewhat irrational, historical experience shows that U.S. policies, even as manifested under the Trump administration, are influenced by its diplomatic strategies, domestic politics, industrial interest groups, think tanks, public opinion and so forth. As a 
matter of fact, President Trump withdrew the United States from the Paris Agreement out of economic considerations and widely-shared skepticism on climate change, and thus the decision was lauded by many (roughly onethird) among the American public. ${ }^{1}$ To fully understand President Trump's exit decision and its impact, however, we need to take into consideration a host of interrelated factors such as the U.S. foreign policy, its political system and party politics, American public opinion, and the role of other countries in global climate governance. This paper attempts to reach a systematic interpretation of the Trump administration's adjustment to the U.S. climate policy as well as its impact on global climate governance. It then discusses how China should shoulder more responsibilities in leading joint global efforts to tackle climate change and in reengaging the United States in the global endeavor.

\section{The Big Reversal: Trump's Climate Policy Readjustment}

Historically speaking, the United States' policy on climate change has always demonstrated a repetitive pattern, reflecting strong "cyclicality" and "variability." As early as the 1960s, President John F. Kennedy called for strengthening research on climate prediction and control as well as efforts for greater international cooperation. Yet it was not until the end of the Cold War that the climate issue really gained prominence on Washington's political agenda. In the early 1990s, the U.S. national security strategy began to list environmental issues as a vital national interest. The G. H. W. Bush administration actively promoted the first United Nations (UN) Environment and Development Conference in 1992 and also the adoption of the UN Framework Convention on Climate Change (UNFCCC). In 1997, the U.S. Department of State (DoS) issued an Environmental Diplomacy Report. In the following year, the Bill Clinton administration signed the Kyoto Protocol.

In contrast to the Clinton administration, the G. W. Bush administration was generally conservative in its approach to environmental issues.

${ }^{1}$ Michael Biesecker and Emily Swanson, “AP-NORC Poll: Few Favor Trump Move to Ditch Paris Accord," Associated Press, June 20, 2017, http://www.apnorc.org/news-media/ Pages/AP-NORC-poll-Few-favor-Trump-move-to-ditch-Paris-accord.aspx. 
In 2001, due to pressure from various domestic interest groups, the U.S. dropped out of the Kyoto Protocol. In 2005, Hurricane Katrina temporarily revived U.S. efforts on global climate issues; and the United States agreed at the Group of Eight (G8) summit in 2008 that a target of 50 percent greenhouse gas emission reduction by 2050 should be met. However, the generally passive attitude toward climate change of the G. W. Bush administration caused a great deal of damage to the multilateral climate system.

When Barack Obama became President in 2009, he clearly stated that he accepted the scientific facts of global warming and was preparing to formulate a series of low-carbon and environmental protection policies. However, due to the defeat of the Democratic Party in the 2010 congressional elections, partisan fighting put an end to many of the positive actions planned for global climate governance. Nevertheless, President Obama was still able to take advantage of the strong and flexible administrative system to promote the signing of the Paris Agreement.

Despite the positive outcomes reached during the Obama era, President Trump quickly reversed most of the policies by his predecessor. He and his supporters basically deny the fact that human activities have intensified climate change. His energy policies are even more controversial. In contrast to the global mainstream promoting clean-energy development and energy structure transformation, President Trump put forward proposals that include revitalizing the coal industry, encouraging the production of traditional oil and gas companies, and reducing investment in renewable energy. Since he took office in January 2017, U.S. climate and energy policies have undergone tremendous changes. Indeed, President Trump's unyielding stance on "counter-reformation" has caused strong public outcry both at home and abroad.

Apart from announcing the U.S. withdrawal from the Paris Agreement and requesting that the UN make "friendlier" amendments to the terms, President Trump has ordered the EPA to audit the Clean Power Plan completely and withdraw the plan if possible. His actions in energy policy include: drastically cutting research funding for energy and climate-related agencies; signing an executive order to restart the construction of the Keystone XL pipeline; increasing investment in the nuclear power industry; and increasing U.S. coal exports. 
By revoking the Clean Power Plan which lies at the core of U.S. domestic climate policy, ${ }^{2}$ the Trump administration has changed its process completely. Moreover, Trump continuously promotes relaxation of standards for emission reductions in various states and enterprises, and he is increasing the scope of fault tolerance to achieve a reduction in Clean Power Plan efficacy. From an economic point of view, President Trump believes that the production costs of clean energy, including solar and wind power, are too high and the return cycle is too long. ${ }^{3} \mathrm{He}$ and his supporters believe that the development of renewable energy industry will rob the traditional energy industry of market share as well as numerous low-skill jobs that would have been provided by it; therefore, it is not conducive to the overall economic prosperity of the United States.

On March 28, 2017, President Trump signed an executive order on Energy Independence, ${ }^{4}$ which orders the EPA and the DoI to audit one of the Obama administration's most remarkable political legacies, the Clean Power Plan, and cancel the plan if necessary. This executive order also requires the repeal of four of Obama's executive orders including the "Power Sector Carbon Pollution Standards" and the "Climate Change and National Security," cancellation of Obama's "Climate Action Plan and Climate Action Plan Strategy to Reduce Methane Emissions," abolition of federal agencies' and departments' guidance on considering the impact of climate change, and dismissal of greenhouse gas assessment.

${ }^{2}$ In August 2015, Obama announced the Clean Power Plan, which is implemented by the U.S. EPA and aims to set emission reduction targets, reduce greenhouse gas emissions from power plants, and contribute to global climate action. The Obama Clean Power Plan has been controversial since it was introduced. It has been opposed by more than 20 states with high energy dependence. These states cooperated with the business community to take the EPA to court and asked the court to rule whether the emission reduction requirements of the plan exceeded the scope of constitutional authority. Among them, Scott Pruitt, head of the EPA appointed by Trump and former Attorney General of Oklahoma, even sued the Environmental Protection Agency under Obama 14 times.

${ }^{3}$ Timothy Cama, “Trump: Wind Power 'Kills All Your Birds,"' The Hill, August 2, 2016 http://thehill.com/policy/energy-environment/290093-trump-wind-power-kills-all-yourbirds.

4 “EPA to Review the Clean Power Plan under President Trump's Executive Order," U.S. Environmental Protection Agency, March 28, 2017, https://www.epa.gov/newsreleases/epareview-clean-power-plan-under-president-trumps-executive-order. 
Furthermore, President Trump announced the U.S. withdrawal from the Paris Agreement on Climate Change, reversing the bottom-up global climate governance process that was once championed by the United States. He claimed that the Paris Agreement was a "punishment" to the United States, and that if the United States fulfilled its commitment of carbon reduction in the agreement, it would lose nearly 3 trillion U.S. dollars in GDP and 6.5 million jobs. Additionally, the Trump administration's refusal to fulfill its climate funding commitment to developing countries and to inject capital into the Green Climate Fund has the potential to greatly dampen global confidence in low-carbon investment. As a result, it is expected that the increase in greenhouse gas emissions from the United States by 2025 will be 500 to 600 million tons of $\mathrm{CO}_{2}$ equivalent. $^{5}$

Clearly, the United States is returning to its traditional energy policy. The first measure is to cut research expenses. On May 23, 2017, the Trump administration released its 2018 fiscal year budget, which mapped out a series of changes in domestic energy policy, mainly

President Trump has largely reversed his predecessor's positive climate policy. reflecting a desire to increase investment in the oil and gas industry as a way of spurring economic growth in the short term and to reduce investment in energy technology research. According to the budget, the EPA's budget for the new year is reduced by 31 percent, and projects such as the Global Climate Change Initiative will no longer be funded by the federal government. Efforts by the National Institutes of Health, NASA, and the National Science Foundation related to energy research will also face budget cuts of 22 percent, 3 percent, and 11 percent respectively. ${ }^{6}$ Besides, the DoE's research section will lose $\$ 3.1$ billion in operating budget, about 18 percent of the previous year's expenditure. The DoE's Energy Efficiency and Renewable Energy Office, which is responsible for solar energy promotion, will face a

5 “Climate Change: Here's Why Paris Accord Unable to Generate Consensus," Financial Express, June 23, 2017, http://www.indiaenvironmentportal.org.in/content/444302/climatechange-heres-why-paris-accord-unable-to-generate-consensus/.

${ }^{6}$ Brad Plumer and Coral Davenport, "Trump Budget Proposes Deep Cuts in Energy Innovation Programs," The New York Times, May 23, 2017, https://www.nytimes.com/2017/ 05/23/climate/trump-budget-energy.html. 
69 percent budget cut. The Fossil Energy Office, responsible for carbon capture technology, will lose 54 percent of its budget; and the Nuclear Power Office responsible for extending the lifespan of existing U.S. nuclear reactors faces a 31 percent reduction in spending. ${ }^{7}$

The second measure is to generate long-term economic benefits by strengthening traditional energy infrastructure. According to the budget, the United States will obtain over $\$ 36$ billion of government revenue by selling energy resources and infrastructure and increasing the development of oil and gas resources over the following decade. This budget will also set up special funds for oil and gas exploration, which is estimated to bring in more than $\$ 1.8$ billion for the government in revenue by 2027. Meanwhile, the budget proposes to invest 37 percent of the oil and gas exploration revenue in the Gulf of Mexico for oil and gas development in Louisiana, Texas, Mississippi and Alabama. In addition, the Trump administration plans to invest $\$ 1$ trillion through public-private partnerships and tax incentives for private investment in energy infrastructure for natural gas, oil, and electricity.

The construction of the Keystone $\mathrm{XL}$ pipeline ${ }^{8}$ is a case in point. The project proposal was rejected by President Obama in November 2015, stating that "it is fair to say that the adoption of this project proposal will undermine the United States' (in dealing with climate change) international leadership." ${ }^{9}$ It was believed that the pipeline would increase the greenhouse effect and damage the environment. This executive order by President Obama was overturned on January 24, 2017 by newly inaugurated President Trump. On that day, he signed a presidential memorandum to announce the restart of construction of the Keystone XL pipeline. On June 29, 2017, President Trump announced a series of energy projects including

${ }^{7}$ Ibid.

${ }^{8}$ The Keystone $\mathrm{XL}$ (hereinafter referred to as $\mathrm{KXL}$ ) oil pipeline is a multinational pipeline project with a total length of approximately 2,700 kilometers and an investment of 7 billion dollars designed and managed by TransCanada. The KXL pipeline connects Alberta, Canada and the Gulf of Mexico, the United States, where crude oil produced in Canada can be sent directly to the Gulf of Mexico. It is the fourth phase of Keystone's overall pipeline project and can be seen as a replication of the pipeline's initial point in the first phase of the project, but with a shorter distance and a larger pipeline flow.

${ }^{9}$ Karl Mathiesen, “Keystone XL Pipeline Rejection Signals U.S. Taking Lead on Climate Change Fight," The Guardian, November 7, 2015, https://www.theguardian.com/environment/ 2015/nov/07/keystone-xl-pipeline-rejection-signals-us-lead-climate-change. 
reassessment of current U.S. nuclear energy policies and ensuring the construction of U.S. coal plants overseas. Reportedly, the Trump administration will increase investment to ensure that nuclear power maintains a share of electricity production in the United States; it will also invest \$120 million in the Yucca Mountain nuclear waste storage site in Nevada to resume the construction of the site that President Obama stopped building. ${ }^{10}$ In his tenure, President Obama lifted the 40-year ban on crude oil exports from the United States and approved 24 liquefied natural gas export licenses. President Trump further extends such lift to coal exports, saying he will increase U.S. coal exports by building coal plants overseas.

The change of the U.S. climate and energy policies is a reflection of political, economic and social characteristics at the domestic level. Faced with multiple and complex environments with increasing political disparity, insufficient economic growth, and extreme social trends, the Trump administration has nearly completely repudiated the past climate policy and abandoned its responsibility toward the international community. From the perspective of political dynamics, this change derives from the party struggle in the United States. The U.S. climate policy not only lacks political consensus between the Democrats and the Republicans, but has also become an increasingly fragmented public issue. The U.S. climate diplomacy decisionmaking process also provides a channel for President Trump to disrupt positive outcomes achieved in the past. From an economic point of view, President Trump's policy shift has been heavily influenced by certain industrial interests and public opinion calling for increasing employment, enhancing industrial competitiveness and addressing the impact of energy structure adjustment. From the perspective of social development, on the one hand, the American public has held much doubt regarding climate change; on the other hand, traditional Republican think tanks like the Heritage Foundation have also been advocating a negative stance toward climate governance.

\section{Gauging Impact of Trump's Climate Policy}

Tackling climate change is one of the most pressing issues in global governance. From the very beginning, the international community has been

${ }^{10}$ Larry Light, “After Trump's Paris Exit, What about Nuclear?," CBS News, June 5, 2017, http://www.cbsnews.com/news/trump-paris-exit-nuclear-power/. 
following a top-down path to promote governance practices based on multilateral consensus, although conflicts among countries and domestic political debates concerning distribution, approaches and methods of climate governance have seriously affected the effect and regime construction of global climate governance. Nevertheless, even with the continuous development of the bottom-up path of climate governance, the influence of states, especially the climate policies of major economies, should not be underestimated.

President Trump's decision to withdraw the United States from the Paris Agreement was a landmark event with regard to the anti-globalization trends around the world. It has become an important case to study in order to understand the backlash of western leadership in global governance. Given the great impact of this decision on global climate governance, it is necessary to assess its potential impact on the U.S. domestic climate governance, the Paris Agreement, and the global climate structure.

U.S. local

governments are expected to play a major role in climate governance.
Admittedly, the U.S. domestic climate governance will face a more uncertain future, for the political consensus necessary for lasting actions is built on the fluctuating public opinion. Once issues that are perceived as more important arise, public pressure on domestic climate governance will diminish. In this sense, President Trump's decision to withdraw from the Paris Agreement does not reflect American rationality, but the vulnerability of American public opinion. ${ }^{11}$ It is possible that today's American society has become more self-concerned and more divided (42 percent of Republicans do not recognize climate change), ${ }^{12}$ but this backlash has created a bind for the rest of the world in the fight against climate change.

With President Trump's negative climate policy, local governments have begun to play a prominent role in the U.S. climate governance. Some

11“The Tale of America's Hollow Climate Change Leadership," Mint, June 1, 2017, https://www.livemint.com/Opinion/Mus3Wx5dpH361or8mtlh1I/The-tale-of-Americashollow-climate-change-leadership.html.

${ }^{12}$ Naomi Oreskes, "The Republican Party — not Trump — is the Biggest Obstacle to Climate Action," The Guardian, June 1, 2017. 
states, represented by California and New York, have launched their own initiatives in terms of regional coordination mechanisms on emission reduction and established a number of urban climate-action network organizations, which provide the cities with political autonomy, financial resources and technical support so that they can actively participate in actions to reduce greenhouse gas emissions. Yet not all the states maintain such an active stance toward climate governance. Some states, in particular those whose economies rely heavily on coal, petroleum, manufacturing, or agriculture, have always opposed President Obama's climate policy. As President Trump has significantly cut research funding and assistance to emission reduction on the federal level, it is hard to say whether local governments in the United States can develop a collective force to push forward domestic climate governance in the country.

With regard to the future of the Paris Agreement, President Trump's withdrawal announcement does not pull the United States from the Agreement immediately as many people believe. According to paragraphs 1 and 2 of Article 28 of the Paris Agreement, "three years after the date of entry into force of this Agreement for a Party, the Party may at any time send a written notification to the Depository to withdraw from this Agreement;" and "any such withdrawal shall become effective on the expiry of one year from the date of receipt of the withdrawal notice or at a later date as stated in the withdrawal notice." This means it will take at least four years for the United States to complete the entire legal process of withdrawal.

However, President Trump's withdrawal announcement has caused great uproar both at home and abroad. As the French National Centre for Scientific Research puts it, "even if the United States cannot completely withdraw from the Paris Agreement in the next four years, the U.S. failure to actively promote the implementation of this document will have an impact on the lives of billions of people."13 Many countries and international organizations including the UN, the European Union (EU), China, France, Germany, and India as well as the Group of Seven (G7) and the Group of Twenty (G20) have expressed their concerns and hopes that the

${ }^{13}$ Max Greenwood, "Climate Scientists Are Very Worried about a Trump Presidency," The Huffington Post, November 10, 2016, http://www.huffingtonpost.com/entry/climatechange-trump_us_5824ead5e4b0f616ef30407a. 
United States could continue its efforts in tackling climate change. For instance, together with other national leaders, German Chancellor Angela Merkel strongly advocated for the Paris Agreement at the G20 Hamburg summit in 2017, urging the United States to continue implementing the Agreement.

The U.S. might stay in the Paris

Agreement in the end.

As a matter of fact, all aspects of the Paris Agreement, including the use of words, legal forms and legal authorization issues, have been tailored to accommodate the United States' needs and concerns, leaving sufficient room for it to shoulder due responsibilities and deliver its promises. Thus, there still exists some possibility for the international community and the American public to persuade the Trump administration (and his successor) to remain in the Paris Agreement.

With regard to the impact of President Trump's withdrawal announcement on future global climate governance, after the U.S. withdrawal from the Paris agreement, developing countries, with China as their representative, are expected to play a bigger "leading" role - as opposed to their former role of "followers" — in global climate negotiations. ${ }^{14}$ They will be given more responsibilities and hence enjoy greater voice in the implementation phase of the Paris Agreement. The "North-South pattern" that previously characterized global climate negotiations is thus weakened, and the U.S. role would be further marginalized. At present, developing countries are working with the EU to continue strengthening the framework for climate governance based on the UNFCCC and the Paris Agreement. ${ }^{15}$

To some extent, the U.S. withdrawal from the Paris Agreement broke the traditional climate governance pattern centered on the EU, the umbrella countries and developing countries during the transition period of the global climate governance paradigm from the Kyoto "dilemma" to the Paris Agreement. First, other parties of the Umbrella Group such as Japan and

${ }^{14}$ Miranda A. Schreurs, “The Paris Climate Agreement and the Three Largest Emitters: China, the United States, and the European Union," Politics and Governance, Vol. 4, No. 3 (2016), pp. 219-223.

${ }^{15}$ Katharina Michaelowa and Axel Michaelowa, "Transnational Climate Governance Initiatives: Designed for Effective Climate Change Mitigation?," International Interactions, Vol. 43, No. 1 (2017), pp. 129-155. 
Australia did not follow this traditional pattern, but developed a " $6+1$ " and "19+1" model with a clear-cut attitude at the G7 and G20 summits respectively, further strengthening the political consensus of the international community. Second, developing countries' status in global climate governance is moving from the edge to the central stage after the U.S. withdrawal decision. Not only does the EU place high expectations on emerging developing countries to play a bigger role, but the NDC (nationally determined contribution) model in the Paris Agreement also requires developing countries to assume more responsibilities in emission reduction. Third, the key actors in global climate governance are changing, for the deregulation of the United States at the national level has further intensified the significance of a "bottom-up" governance model by various non-state actors.

Indeed, this "bottom-up" model has become increasingly important in climate governance during the post-Paris Agreement era. Based on a framework of multidimensional power for non-state actors to participate in global governance, this paper focuses on the path of the U.S. local climate actions to strengthen its governance authority in the context of President Trump's withdrawal policy. It can be seen that the stronger local leadership in climate actions will help shape a new pattern in global climate governance: the rising status of non-state actors in international law provides a political opportunity for their direct influence on policy formulation; in future climate negotiations, they are expected to exercise more discourse power with their local governance practices and norms.

\section{Whither China-U.S. Cooperative Leadership?}

From the 1990s to the present, the global climate governance structure, with the UN climate negotiations at its core, has undergone substantial changes, resulting in many milestone accomplishments such as the UNFCCC, the Kyoto Protocol, and the Paris Agreement. The UNFCCC, in particular, lays the basic framework for the global climate governance system. President Trump's withdrawal announcement is undoubtedly a huge blow to the enthusiasm of countries participating in global climate governance. Against this backdrop, the once-highlighted joint leadership role of China and the United States is diminishing.

In retrospect, China-U.S. cooperation at the final stage of the Copenhagen Climate Change Conference was a precursor of their joint leadership 
in global climate governance. Since the Joint Statement on Climate Change between China and the United States was issued in 2013, China and the United States have issued multiple statements on climate governance cooperation and carried out fruitful cooperative actions at the bilateral level. They have also worked together to promote the signing of the landmark Paris Agreement at the multilateral level. Unfortunately, President Trump's negative stance toward climate governance and especially his decision to withdraw the United States from the Paris Agreement seem to have put a stop to China-U.S. cooperation on climate change, at least for the time being.

The China-U.S.

cooperative

leadership in global

climate governance is

losing relevance.

China and the United States used to be able to reach consensus on such issues as greenhouse gas emission reduction targets, the "common but differentiated responsibilities (CBDR)" principle, and emission reduction constraint mechanisms before they could arrive at a wider consensus with the EU, thus they shared a cooperative leadership in global climate governance (see Table 1). With the fading willingness and input on the U.S. side, however, the China-U.S. cooperative structure has been stranded, and the international community is once again faced with a leadership deficit. ${ }^{16}$

Above all, the United States is making much less effort in emission reduction at the national level, and its central role in global climate governance has been significantly eliminated. In view of the fact that China and the United States are two of the world's biggest greenhouse gas emitters, whose emissions account for 43 percent of the world's total, whether they can work together to provide necessary leadership is key to the outcome of global emission reduction efforts. However, the Trump administration has neither the willingness to fulfil its emission reduction commitments nor the intention to maintain its leadership role.

16"Statement by President Trump on the Paris Climate Accord," The White House, August 8, 2017, https://www.whitehouse.gov/the-press-office/2017/06/01/statement-presidenttrump-paris-climate-accord; and Robert N. Stavins, "Why Trump Pulled the U.S. Out of the Paris Accord," Foreign Affairs, June 5, 2017, https://www.foreignaffairs.com/articles/2017-06-05/ why-trump-pulled-us-out-paris-accord. 
Table 1. Changes in the China-U.S. Cooperative Leadership Structure in Global Climate Governance.

\begin{tabular}{|c|c|c|}
\hline & The Obama Administration & The Trump Administration \\
\hline $\begin{array}{l}\text { Ability to } \\
\text { Cooperate }\end{array}$ & $\begin{array}{l}\text { China and the United States adopted } \\
\text { effective action plans for emission } \\
\text { reduction, promulgated important } \\
\text { laws and regulations, and invested } \\
\text { large amounts of funds. }\end{array}$ & $\begin{array}{l}\text { The United States has refused } \\
\text { to provide funding and } \\
\text { other support, while China } \\
\text { maintains its previous } \\
\text { commitment. }\end{array}$ \\
\hline $\begin{array}{c}\text { Willingness to } \\
\text { Cooperate }\end{array}$ & $\begin{array}{l}\text { Both countries made positive } \\
\text { commitment and expressed their } \\
\text { strong desire to jointly lead } \\
\text { global climate governance. }\end{array}$ & $\begin{array}{l}\text { The United States has no } \\
\text { intention to fulfil its } \\
\text { commitment or lead global } \\
\text { climate governance. China's } \\
\text { willingness to cooperate has } \\
\text { not diminished. }\end{array}$ \\
\hline $\begin{array}{l}\text { Differences in } \\
\text { Cooperation }\end{array}$ & $\begin{array}{l}\text { Both countries effectively bridged } \\
\text { their gap in the CBDR principle, } \\
\text { with a strong consensus on } \\
\text { establishing a "bottom-up" } \\
\text { constraint mechanism. }\end{array}$ & $\begin{array}{l}\text { Significant differences arise } \\
\text { between both countries on } \\
\text { "whether climate change is } \\
\text { real," "whether to withdraw } \\
\text { from the Paris Agreement," } \\
\text { and other issues alike. }\end{array}$ \\
\hline Results & $\begin{array}{l}\text { Rapid development of the } \\
\text { China-U.S. Cooperative } \\
\text { Leadership Structure }\end{array}$ & $\begin{array}{l}\text { Stagnation and stranding of the } \\
\text { China-U.S. Cooperative } \\
\text { Leadership Structure. }\end{array}$ \\
\hline
\end{tabular}

Source: Compiled by the author.

Next, the Trump administration is apparently focusing on economy instead of climate diplomacy. In practice, climate diplomacy aims to achieve specific climate governance goals and promote climate cooperation by three diplomatic means, namely persuasion, appeal and enforcement. However, the Trump administration seems to have no intention to use its diplomatic resources to persuade other climate actors to identify, participate in and accept specific climate governance action plans. Even worse, it has by and large denied the necessity of global climate governance. It is thus difficult for China to promote the climate governance process alone when its own appeal is relatively limited. Additionally, as the global climate governance mechanism is non-legally binding, it requires certain harsh diplomatic measures by China and the United States to prevent and redress serious violations of existing agreements on climate governance by other members of the international community. After the U.S. withdrawal from the Paris Agreement, however, such constraints no longer exist. 
Finally, the Trump administration's climate policy has not only undermined the U.S. image as a responsible leader of global governance, but also set a bad example to other members of the international community. The Obama era witnessed ever closer and more effective China-U.S. cooperation in global climate governance; their emission reduction commitments served as positive signals and provided strong momentum for collective efforts of the international community to address climate change. With President Trump's withdrawal decision, however, some other countries may follow suit or at least develop a passive stance toward emission reduction and begin to adopt lower-standard climate policies.

In short, after an overhaul of the U.S. climate policy, the Trump administration's willingness to participate in global climate governance is obviously lacking, which has widened the gap between the United States and other major parties in the governance process. The China-U.S. cooperative leadership, once pivotal to fostering strong collective actions of the international community in tackling climate change, is now dormant, causing serious leadership deficits in global climate governance for the time being. Yet the United States will not stay out of the global climate governance process forever, not least because there is strong domestic public opinion for the federal government to resume a positive attitude toward climate governance. In the long run, the international and domestic driving forces are likely to push the United States back to the global climate governance process and revive the cooperative leadership structure of China and the United States - very possibly with some other major parties like the EU and India playing a bigger role depending on how much they will carry out their commitments in the years to come.

\section{China's Future Climate Actions}

As mentioned before, the United States' sudden renouncement of climate leadership departs strikingly from its joint efforts with China underlying the Paris Agreement, and leads the world to pin their hopes on China. Many have commented that the United States is ceding climate leadership to China and China should grasp this rare opportunity to assume a leading role in global climate governance for its own benefits and to consolidate its great-power status. Indeed, it is time for China to reassess and redefine its role in global climate governance. 
Leadership is costly. Despite decades of economic and social progress, China remains a developing country, and the Chinese leadership has reiterated that China's international contribution should always be commensurate with its capabilities. Now that the Trump administration has adopted a negative climate policy and the China-U.S. cooperative leadership is no longer existent, China should respond positively to the general expectation of the international community and make necessary adjustments to its climate policy.

First, China needs to try to play a more active role in climate governance and continue to promote the global governance process under existing mechanisms. Domestically, it should continue to encourage the revolution of production and consumption in the energy sector, and strictly implement related law and regulations to reduce domestic greenhouse gas emissions gradually, so as to set a good example for other countries. ${ }^{17}$ To strengthen international cooperation, China needs to maintain close contact with other actors in global climate governance, conducting political dialogue, technical negotiations, and academic exchange at all levels. More diplomatic resources need to be put into climate cooperation with other countries under the UNFCCC and especially among the BASIC countries including Brazil, South Africa, India and China, for they share common interests and responsibilities in global climate governance as major developing countries.

Second, China should rise up to the challenge of surmounting uncertainties brought about by the U.S. withdrawal from the Paris Agreement. China's position on the Paris Agreement was explicitly stated in President Xi's speech entitled "Work Together to Build a Community of Shared Future for Mankind" at the UN Office of Geneva in January 2017. As he declared, "The Paris Agreement is a milestone in the history of climate governance. We must ensure this endeavor is not derailed. All parties should work together to implement the Paris Agreement. China will continue to take

${ }^{17}$ Chinese President $\mathrm{Xi}$ Jinping reaffirmed on many occasions that "China will continue its efforts in mitigating climate change and fulfilling its obligations by one hundred percent." See, for example, "Xijinping 'lusezhili' guan: shijierentong tixian zhongguodandang [Xi Jinping's 'Green Governance' Outlook: The World Recognizes China's Shouldering More Responsibilities]," People.cn, June 7, 2017, http://jx.people.com.cn/n2/2017/0607/c190316-30290021. html. 
steps to tackle climate change and fully honor its obligations." ${ }^{18}$ To sustain global confidence and endeavors in climate governance, China should strongly advocate such notions as low carbon cities, energy poverty alleviation, renewable energy industry and smart grids on various international platforms, including the G20 summit to be held in Argentina toward the end of 2018. As China is not in a position to fill in the leadership vacuum left by the United States due to its limited political, economic and other resources, it should help foster a shared leadership with such key partners as the EU, Japan and other BRICS countries.

Third, China should make more efforts to encourage domestic and international financing for climate governance. China is already the largest issuer of "green bonds;" and the participation of its private sector in climate financing has been on the rise over the past few years. It needs to work with other major economies to increase their green aid to developing countries by setting up a global environment fund, green climate fund and other funding institutions. This is not only conducive to China's own ecological development, but it will also enhance China's leading role in global climate governance.

China should strengthen climate cooperation with individual U.S.

states.

Fourth, in view of President Trump's negative climate policy, China should try to expand cooperation with local governments in the United States for the time being. ${ }^{19}$ According to statistics, despite President Trump's passive attitude, 32 U.S. states have taken active measures to combat climate change and expressed their disapproval of President Trump's climate policy as well as their support for climate governance (see Table 2). California, New York and Arizona have even become models for other states in terms of climate mitigation. Strengthened cooperation with those "states of the willing" will

18 "Work Together to Build a Community of Shared Future for Mankind," Xi Jinping's Speech at the United Nations Office at Geneva, January 18, 2017, http://www.xinhuanet. com/english/2017-01/19/c_135994707.htm.

${ }^{19}$ Qi Ye and Manish Bapna also expressed similar views in a seminar on "Sino-U.S. Action and Cooperation under the New Global Climate Governance Pattern" held at Tsinghua University on May 24, 2017. 
Table 2. U.S. State Governments' Attitude towards Climate Mitigation.

\begin{tabular}{|c|c|c|}
\hline Positive Response & $\begin{array}{l}\text { Negative } \\
\text { Response }\end{array}$ & $\begin{array}{l}\text { Undecided } \\
\text { or Unclear }\end{array}$ \\
\hline $\begin{array}{l}\text { California, Arizona, Connecticut, } \\
\text { Pennsylvania, New York, South Carolina, } \\
\text { Massachusetts, New Hampshire, Rhode } \\
\text { Island, Wisconsin, New Mexico, South } \\
\text { Dakota, Colorado, Minnesota, Illinois, } \\
\text { Utah, Maryland, Vermont, Oregon, } \\
\text { Montana, New Jersey, Maine, Delaware, } \\
\text { Wyoming, North Carolina, Michigan, } \\
\text { Hawaii, Louisiana, Nevada, Missouri, Iowa, } \\
\text { Washington } \\
32\end{array}$ & $\begin{array}{l}\text { Oklahoma } \\
\text { West Virginia } \\
\text { Ohio } \\
\text { Kansas } \\
\text { Florida } \\
\text { Alabama } \\
\text { Arkansas } \\
\text { Texas } \\
\text { Kentucky }\end{array}$ & $\begin{array}{l}\text { Alaska } \\
\text { Georgia } \\
\text { Indiana } \\
\text { Mississippi } \\
\text { Idaho } \\
\text { Virginia } \\
\text { North Dakota } \\
\text { Nebraska } \\
\text { Tennesse }\end{array}$ \\
\hline
\end{tabular}

Source: Compiled by the author. ${ }^{20}$

both alleviate the negative impact of the Trump administration's negative climate policy and exert lasting pressure on the administration to change course at a certain time in the future.

Fifth, China must make every effort to reengage the U.S. federal government in global climate governance in the longer run. In spite of the changing attitudes of different U.S. administrations, the China-U.S. cooperative leadership in climate governance is indispensable for joint global endeavor and is very likely to recover as time goes by. The G. W. Bush administration withdrew from the Kyoto Protocol and then returned to the Bali Conference on climate change a few years later. Similarly, President Trump announced the U.S. withdrawal from the Paris Agreement, but the United States is still a party in the UNFCCC, and all signatories of the Paris Agreement have reserved room for its return. The U.S. federal government may well consider rejoining the Agreement if it finds it necessary to meet future political or economic dynamics of the country.

${ }^{20}$ The author has mainly examined the U. S. states' action plans and policies, statements made by the governors, and climate policy traditions. States that have not indicated a clear attitude, have not taken active moves, or have indicated obvious contradictions in their position and actions are classified as "undetermined." For sure, the boundaries between the supportive, opposing and undetermined groups are relatively vague. There are numerous reference materials that may be consulted for a more conclusive perspective. 
To facilitate that, China should try to maintain the existing bilateral technical working group and support the regional summit of low carbon cities in China and the United States. Besides, it can promote common climate projects on sustainable infrastructure investment, shale oil and gas trade, and haze governance, combined with other issues on energy efficiency, natural gas, clean coal, clean air and water, etc., that is of much concern to the Trump administration, so as to revitalize climate cooperation with the United States.

\section{China must facilitate participation of non-state actors in global climate cooperation.}

Finally, China should foster domestic social forces to better cope with global climate governance. Compared with western countries, most developing countries, China included, lack the experience and institutions for long-term interaction between the government and non-state actors, which has undermined their creativity, technical capabilities and power of discourse in global climate cooperation. Especially in the follow-up negotiation on details regarding the Paris Agreement, the expertise and experience of the scientific circle, the academia and the business community are to be better employed - not just to lend support to the government, but also for the principles of fairness and transparency that are clearly stipulated in the Agreement. Although the most active non-state actors are generally from developed countries, whose pursuit of interests usually reflects and reinforces their respective government's position, it is a necessary step for China if it is to fulfil its commitment as a responsible leader in global climate governance. In this process, the vision and wisdom of the Chinese government will be further tested in determining how to achieve positive interaction with various non-state actors and how to play a leading role in global efforts while ensuring its own basic interests.

\section{Conclusion}

At present, the global climate governance system faces dual challenges from both institutional deficiencies and lingering discrepancies among countries. Cooperative leadership of major economies - in particular China, the United States and the EU - is in more urgent need to sustain 
global actions to tackle climate change. During the Obama administration, a close cooperative leadership structure was built between China and the United States thanks in large part to their effective decision-making process in bridging their technical differences on the path toward reaching the Paris Agreement. As President Trump adopts a very negative stance toward climate governance and tries to withdraw the United States from the Paris Agreement, the China-U.S. cooperative leadership has ceased to exist for the time being. Global climate governance once again suffers from serious leadership deficits.

In light of this, China as the biggest greenhouse gas emitter should take more responsibility in promoting global cooperation under different mechanisms. Most importantly, it should fulfil its own commitments in emission reduction and global aid, and make every effort to reengage the United States in the joint endeavor of the international community in tackling climate change. After all, the many achievements of China-U.S. climate governance cooperation over the past two decades should not be wiped off due to the whim or consideration of short-term benefits of any single administration. 